\title{
The Land Use and Cover Change in Miombo Woodlands under Community Based Forest Management and Its Implication to Climate Change Mitigation: A Case of Southern Highlands of Tanzania
}

\author{
Z. J. Lupala, ${ }^{1}$ L. P. Lusambo, ${ }^{2}$ Y. M. Ngaga $^{2}$ and Angelingis A. Makatta ${ }^{3}$ \\ ${ }^{1}$ Ministry of Natural Resources and Tourism, Forestry Training Institute, Arusha, Tanzania \\ ${ }^{2}$ Department of Forest Economics, Sokoine University of Agriculture, Morogoro, Tanzania \\ ${ }^{3}$ Institute of Resource Assessment (IRA), University of Dar es Salaam, Dar es Salaam, Tanzania \\ Correspondence should be addressed to Z. J. Lupala; zachlupala@yahoo.com
}

Received 26 December 2014; Revised 23 February 2015; Accepted 23 February 2015

Academic Editor: Guy R. Larocque

Copyright (c) 2015 Z. J. Lupala et al. This is an open access article distributed under the Creative Commons Attribution License, which permits unrestricted use, distribution, and reproduction in any medium, provided the original work is properly cited.

In Tanzania, miombo woodland is the most significant forest vegetation with both ecological and socioeconomic importance. The vegetation has been threatened from land use and cover change due to unsustainable utilization. Over the past two decades, community based forest management (CBFM) has been practiced to address the problem. Given the current need to mitigate global climate change, little is known on the influence of CBFM to the land use and cover change in miombo woodlands and therefore compromising climate change mitigation strategies. This study explored the dynamic of land use and covers change and biomass due to CBFM and established the implication to climate change mitigation. The study revealed increasing miombo woodland cover density with decreasing unsustainable utilization. The observed improvement in cover density and biomass provides potential for climate change mitigation strategies. CBFM also developed solidarity, cohesion, and social control of miombo woodlands illegal extraction. This further enhances permanence, reduces leakage, and increases accountability requirement for carbon credits. Collectively with these promising results, good land use plan at village level and introduction of alternative income generating activities can be among the best options to further reduce land use change and biomass loss in miombo woodlands.

\section{Introduction}

Miombo woodland is a vernacular word that has been adopted by ecologists to describe those woodlands dominated by trees of the genera Brachystegia, Julbernardia, and Isoberlinia Leguminosae, subfamily Caesalpinioideae $[1,2]$. The woodlands cover between 2.7 and 3.6 million $\mathrm{km}^{2}$ in 11 countries of Africa [3-5]. In Tanzania, this vegetation type covers more than $90 \%$ of forested land [6-8]. Miombo woodlands provide a wealth of public services and private goods, including valuable resource for both rural and urban communities [9-12]. The woodlands form an integral part to socioeconomic and cultural aspects of local communities [11, 13]. They also serve as safety net in times of distress and stress [3, 11, 14]. According to the World Bank [15], it is estimated that
1.6 billion people depend on tropical forests and woodlands for their daily needs. For example, in Tanzania, miombo woodlands support the livelihoods of estimated $87 \%$ of urban and rural population $[12,16]$. The population uses range of goods such as fuel wood, charcoal, fruits, mushrooms, and many other ecosystem services derived from miombo woodlands. Elsewhere, there is also a steady flow of goods and services from miombo woodlands to rural and urban areas [17].

Miombo woodlands are also important for carbon storage and sequestration [18, 19], biodiversity habitats [17], and timber and nontimber products $[8,20]$. Yet despite all these, the woodlands are being steadily converted to other uses such as pasture, fuel wood extraction zones, and farmlands which can generate greater private economic returns [21]. 
Approximately 13 million ha of forests is cleared annually to provide livelihoods, incomes, and employment for millions of people in the tropics $[20,22]$. As a result land use and forest cover change in the tropics and miombo woodlands remain an enormous challenge with concomitant social, environmental, and economic implications $[9,16]$. The land use and cover change also have effects on carbon storage and sequestration potentials [23]. For example, without land use and cover change the miombo woodland is estimated to have carbon sink strength of about $0.39 \mathrm{GtC}$ year $^{-1}$ [18]. However, between 1990 and 1999 the average annual flux of carbon to the atmosphere due to land use and cover change in miombo woodlands was estimated at $0.35 \pm 0.2 \mathrm{GtC}_{\text {year }}{ }^{-1}$ $[19,24,25]$. This implies that land use and cover change in miombo woodlands are reducing global carbon sink strength.

There is an increasing recognition that emissions of GHGs from land use and cover change in the tropical countries account for 20-25\% of total global emissions [26]. United Nations Framework Conversion on Climate Change (UNFCCC) is actively concerned with mitigation of GHGs emission from land use and forest cover changes [27, 28]. The target is to reduce between 10 and $15 \%$ of GHGs emissions resulting from land use and forest cover change [28, 29]. According to Sunderlin et al. [30, 31], and Skutsch et al. [32] community managed forests are important component for global climate change mitigation strategy. The management comprises more than $10 \%$ of forest globally [20, 24, 33].

This type of forest management and property right has often been manifested in various developing countries including Tanzania [34-36]. In Tanzania Participatory Forest Management (PFM) is a general term describing community involvement in management of forests. Community Based Forest Management (CBFM) is one kind of PFM approach taking place on village land [37]. This approach is a central element in both forest policy of 1998 and forest Act of 2002 $[7,38]$. Usually community signs an agreement with the government and management plan is drawn for a given area of forest. This provides right and responsibilities to local communities $[36,39,40]$. In this study CBFM is referred to as "de-jure" government approved forms of forest management by local communities. This provides local communities with social and economic benefits whilst promoting the sustainable forest management. There must be some degree of control and decision-making power vested in the community by the government or other designated authorities [31, 40].

The management provides full ownership of the forest and rights to sustainable management and utilization of forest products such as fire wood, fodder, medicinal plants, mushroom, and fruits and in some cases also timber [7, 41]. Despite these, challenges still remain on economic benefits and welfare improvement $[30,33,36]$, particularly in miombo woodlands $[13,42]$. However, this is not withstanding; Tanzania is one of the leading countries of Africa legally practicing forest management based on community based framework $[7,35,36]$. The common agreed characteristics embedded within it are that local people have capacity of undertaking useful role in forest management and have a legitimate right to participate $[29,43,44]$.

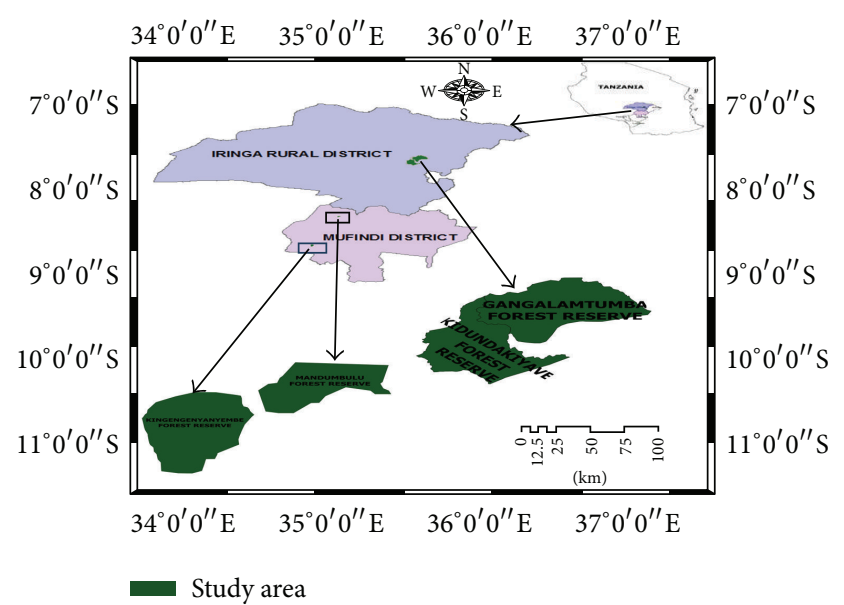

FIGURE 1: Map showing the location of the study areas and the respective forest reserves.

The argument that forests can be better managed when forest users are involved in making and adapting rules on the exclusion or inclusion of participants, defining their obligations, agreeing appropriate management strategies, monitoring impacts, and resolving conflicts is being accepted [40, 43, 45, 46]. Thus CBFM has been widely embraced (e.g., $[43,46])$ but has not yet been appreciably in the global efforts to mitigate climate change [47]. This could be due to limited knowledge and information about land use change due to CBFM and its implication to climate change mitigation. This compromises global climate change mitigation strategies [32, 47]. However, CBFM could be one weapon in the struggle to mitigate global climate change [48]. Therefore this study examined land use and covers change in miombo woodlands under CBFM and established the implication for climate change mitigation policy.

\section{Materials and Methods}

2.1. The Description of the Study Area. This study was carried out in Iringa region located in Southern Highlands of Tanzania, between $6^{\circ} 55^{\prime}$ and $10^{\circ} 30^{\prime}$ south of Equator and between longitudes $33^{\circ} 45^{\prime}$ to $36^{\circ} 55^{\prime}$ east of Greenwich (Figure 1). Ecologically, the study sites represent miombo woodland forests, dominated by genera Brachystegia, Julbernardia, and Isoberlinia species in a relatively flat area at 1,200-1,500 m.a.s.l. The selected districts were Mufindi district situated at about $80 \mathrm{~km}$ from Iringa municipality along Dar es Salaam-Mbeya to Zambia main road. Iringa rural district is situated about $30 \mathrm{~km}$ from Iringa municipality. Mufindi district and Iringa rural district of Iringa region were purposively selected due to the presence of miombo woodlands under community based management regimes.

CBFM in the study area started from 2003 through Iringa District Council cooperation with Danish International Development Assistance, Danida [50]. This cooperation was named MEMA, HIMA, and CONCERN projects [50]. Ever 
TABLE 1: Biophysical and climatic characteristics of studied miombo forest reserves by 2011 [14].

\begin{tabular}{|c|c|c|c|c|c|c|c|}
\hline District & Forest name & Area (ha) & Location & Altitude (m) & $\begin{array}{c}\text { Dominant } \\
\text { soil type }\end{array}$ & $\begin{array}{c}\text { Mean temp. } \\
\left({ }^{\circ} \mathrm{C}\right)\end{array}$ & $\begin{array}{c}\text { Mean rain } \\
(\mathrm{mm})\end{array}$ \\
\hline \multirow{2}{*}{$\begin{array}{l}\text { Iringa rural } \\
\text { district }\end{array}$} & Gangalamtumba & 6,065 & $\begin{array}{c}7^{\circ} 35^{\prime} \mathrm{S} . \\
35^{\circ} 35^{\prime} \mathrm{E} .\end{array}$ & $850-1,300$ & $\begin{array}{l}\text { Sandy clay } \\
\text { loam soils }\end{array}$ & 19.8 & 617 \\
\hline & Kidundakiyave & 4904 & $\begin{array}{c}7^{\circ} 59^{\prime} \mathrm{S} . \\
35^{\circ} 79^{\prime} \mathrm{E} .\end{array}$ & $850-1,300$ & Clay alluvial soils & 21.5 & 600 \\
\hline \multirow{2}{*}{$\begin{array}{l}\text { Mufindi } \\
\text { district }\end{array}$} & Mandumburu & 450 & $\begin{array}{c}8^{\circ} 43^{\prime} \mathrm{S} . \\
35^{\circ} 64^{\prime} \mathrm{E} .\end{array}$ & $1180-1500$ & $\begin{array}{l}\text { Sandy loam } \\
\text { soils }\end{array}$ & $24.6^{\circ} \mathrm{C}$ & 630 \\
\hline & Kingegenyanyembe & 459.6 & $\begin{array}{l}8^{\circ} .00^{\prime} \mathrm{S} . \\
35^{\circ} 15^{\prime} \mathrm{E} .\end{array}$ & $1600-1800$ & $\begin{array}{l}\text { Sandy clay } \\
\text { soils }\end{array}$ & $22.6^{\circ} \mathrm{C}$ & 584 \\
\hline
\end{tabular}

Source: village governments' records [49].

TABLE 2: Study district and village, sample size, and forest name used in data collection.

\begin{tabular}{lcccc}
\hline District & Forest name & Forest size (ha) & Village name & Households size \\
\hline \multirow{2}{*}{ Mufindi } & Kingegenyanyembe & $459.6(30)$ & Kingegenyanyembe & $606(60)$ \\
& Mandumburu & $450(30)$ & Tambalangombe & $462(46)$ \\
\multirow{2}{*}{ Iringa rural } & Gangalamtumba & $6,065(30)$ & Mfyome & $648(64)$ \\
& Kidundakiyave & $4,904(30)$ & Kihwele & $479(48)$ \\
\hline Total & Four forests & $11,878.6(120)$ & Four villages & $2,195(218)$ \\
\hline
\end{tabular}

${ }^{*}$ Number in parenthesis is sampling intensity for both ecological and socioeconomic data.

since, this area remained the best in community based forest management practices in Tanzania $[35,50]$. The general climate of the area is bimodal with rain season in October to May and dry season in June to September. The mean annual rainfall is $500-600 \mathrm{~mm}$ and the mean annual temperature app. $21^{\circ} \mathrm{C}$ (Table 1). Most of the area is dominated by clay and sandy soils with high swelling and shrinkage characteristics.

2.2. Data Collection. The selected forest reserves were stratified into relatively small homogeneous stands through visual interpretation of the georeferenced satellite imageries at a scale of $1: 50000$. The standard sheets of topographical maps 1:50000 and Land Cover and Land Use map of Iringa $1: 250,000$ were used to show the distribution of land cover and land use in Southern Highlands of Tanzania. In each stratum, sample plots were systematically laid out along transects at an interval of $200 \mathrm{~m}$ to $200 \mathrm{~m}$ between plots. Transect orientation was based on spatial distribution of road network passing through the reserves. To minimize the edge effect, the plot centre for the first plot was half the prescribed plot interval from the road edge. Each sample plot was set out on the ground and its corresponding coordinate was recorded using a hand held GPS (Garmin GPS etrex $60 \mathrm{CSx}$ ) receiver having \pm 3 level of precision. The forest inventory techniques followed described procedure by MacDicken [51] and MNRT [38] and from good practice guidance for land use, land use change, and forestry [52].

The forest inventory was carried out in both CBFM forests and adjacent non-CBFM or open access forest as a baseline and referred to as business as usual. In total 120 concentric sample plots of 0.07 ha were surveyed in CBFM and 90 plots surveyed in business as usual. The plots had radius of $2 \mathrm{~m}$ for tree diameter $\geq 1 \mathrm{~cm}, 5 \mathrm{~m}$ for $\geq 5 \mathrm{~cm}, 10 \mathrm{~m}$ for $\geq 10 \mathrm{~cm}$, and $15 \mathrm{~m}$ for $\geq 20 \mathrm{~cm}$. This plot shape ensured measurement of both small and larger tree diameters and also increased accuracy in measurement. Moreover, the $15 \mathrm{~m}$ radius is comparable with the spatial resolution of Landsat TM and ETM+ $[4,5,53]$. In each plot, tree diameter at breast height $(\mathrm{cm})$, stump basal diameter $(\mathrm{cm})$, plot number, slope, aspect, species name, and coordinates were recorded. In addition, Landsat images for 2000 before CBFM and 2013 after CBFM were used to analyze land use and miombo woodlands cover changes. All images were acquired during dry season between June, July, and September so as to minimize seasonality and cloud. The image Landsat ETM+ with Path/Row 168/66 and acquisition date 28 th/09/2013 and 168/65 of 10/07/2013 was used to detect change after ten years of CBFM implementation, while the image Landsat TM with Path/Row 168/66 and acquisition date 18 th/06/2000 and 168/65 of 24th/09/2000 was used to analyze before CBFM as a relative base case.

An allowable error of $10 \%$ was used in both ecological and socioeconomic data collection as suggested by Zahabu [7] and Lusambo [9] (Table 2). Participatory Rural Appraisal (PRA), questionnaire survey, and checklists were major methods in collection of socioeconomic data. The sampling frame for socioeconomic data was the list of all households in the village register.

2.3. Data Analysis. Tree species lists and codes were prepared and the diameter at breast height (dbh) was entered in excel spreadsheet. Various forest parameters were computed to determine forest stocking (volume, biomass, and carbon), tree species composition, structures, and regeneration potentials. The selection of appropriate allometric equations for computation of both volume and biomass was done through pretested locally available allometric equations. The general allometric equation for above ground biomass computation for miombo woodlands of Tanzania developed by 
Mugasha et al. [54] was used. This equation includes trees greater than $1 \mathrm{~cm}$ diameter at breast height $(\mathrm{dbh})$ and it has the advantage of requiring only $\mathrm{dbh}$ as independent variable. Among others, the equation included miombo woodlands from Iringa region and also had $R^{2}$ of $95 \%$ making it most reliable. The equation is as follows:

$$
\text { Biomass }=0.1027 \mathbf{D}^{2.4798}
$$

where biomass $=$ total tree biomass $(\mathrm{kg})$ and $\mathbf{D}=$ tree $\mathrm{dbh}$ $(\mathrm{cm})$. The estimated biomass was then converted to carbon using biomass carbon ratio of 0.5 and then multiplied by 3.67 to get equivalent $\mathrm{tCO}_{2} / \mathrm{ha}$ [51].

Above ground biomass was determined but not soil carbon. The reasons for this exclusion are the technical difficulties to estimate change in soil carbon over time [51]. In addition, it is not yet clear whether soil carbon will generate carbon credits under REDD+ [32]. The total tree volume was calculated from the allometric equation developed by Malimbwi et al. [55] for miombo woodlands of Tanzania. The equation is $\mathbf{V}=0.000011972 \mathbf{D}^{3.191672}$ where $\mathbf{V}=$ tree volume $\left(\mathrm{m}^{3}\right)$ and $\mathbf{D}=$ tree $\mathrm{dbh}(\mathrm{cm})\left(R^{2}=0.98\right)$. Diameter at breast height of stump was obtained by regression of height to basal diameter of sample trees developed by this study $\left(\mathrm{Ht}=4.234+0.254(\mathrm{bd}), R^{2}=0.78, P<0.0001\right)$.

Images enhancement was performed using a 4,5,3 color composite band combination and its contrast was stretched using the Gaussian distribution function followed by high pass filter $3 \times 3$ to increase the visibility of the ground control points in both images. Base maps were prepared based on the image acquired on July 7, 2013, and used in ground truething exercise. The essence of conducting ground true-thing was to verify different covers types as described on the base maps and for collection of ground points for the classification accuracy assessment. Supervised classification, using maximum likelihood classifier [56, 57], was performed using ILWIS software. Training fields were identified by inspecting an enhanced colour composite imagery. Areas with similar spectral characteristics were trained and classified. Five land cover classes were developed, namely, closed miombo woodlands, open miombo woodlands, bushed grasslands, cultivated lands, and unclassified lands. Land cover maps for the years 2000 and 2013 were developed and later used in change detection using image differencing [53].

To analyze the changes between different time epochs, change detection analysis was performed. There are many change detection methods developed and used for various applications [58]. However, they can broadly be divided into postclassification approaches and spectral change detection approaches [56]. In this study, image differencing was used as a method of choice for change detection whereby the thematic classified images were differenced. This algorithm involves subtracting one epoch of the classified imagery from a second epoch of classified imagery that has been precisely registered to the first. It normally results into positive and negative values representing areas of change and zero values representing no change. The postclassification change detection method was applied followed by spatial overlay analysis in ArcGIS environment resulting into attribute tables. The

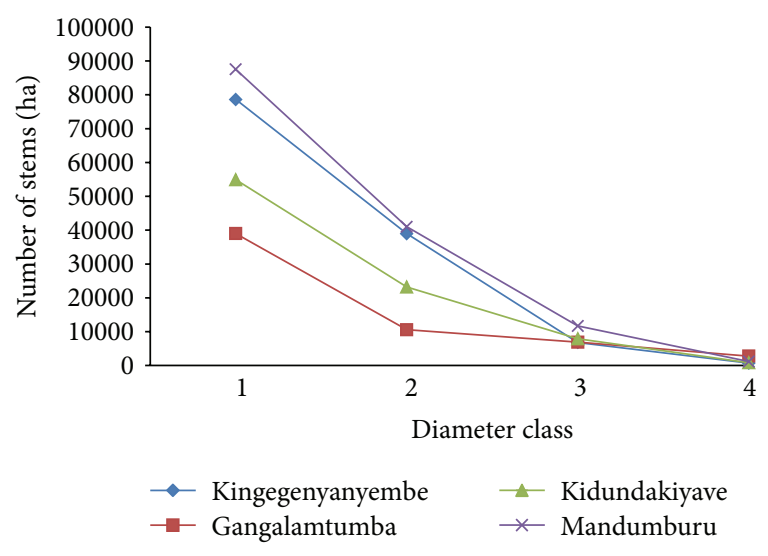

FIGURE 2: Distribution of tree diameter class in studied miombo woodlands.

tables were exported to MS Excel to compile area change detection matrix for 2000-2013 period. The estimation for the rate of change for the different covers was computed based on the following formulae (2) [56]:

$$
\begin{gathered}
\text { Change }_{\text {year } x}=\frac{\text { Area }_{i \text { year } x}-\text { Area }_{i \text { year } x+1}}{\sum_{i=1}^{n} \operatorname{Area}_{i \text { year } x}} \times 100, \\
\begin{aligned}
\text { Annual rate of change }= & \frac{\text { Area }_{i \text { year } x}-\text { Area }_{i \text { year } x+1}}{t_{\text {years }}}, \\
& \\
& \times 100,
\end{aligned}
\end{gathered}
$$

where Area $_{i \text { year } x}=$ area of cover $i$ at the first date, Area $_{i \text { year } x+1}$ $=$ area of cover $i$ at the second date, $\sum_{i=1}^{n} \operatorname{Area}_{i \text { year } x}=$ the total cover area at the first date, and $t_{\text {years }}=$ period in years between the first and second scene acquisition dates.

Moreover, the socioeconomic data was analyzed thematically at the point of collection in participatory way with the help of local communities. Content analysis was used to analyze components of verbal discussions held with different respondents, while structural-functional analysis was used to explain the way social factors relate to each other within social system and manner they relate to the physical surroundings [59].

\section{Results and Discussion}

3.1. Stocking Parameters Describing Miombo Woodlands of the Study Area. The analyses of miombo woodland structure and stocking parameters are shown in Table 3 and Figure 2. A total of 88 species were recorded and dominant species were Brachystegia species as expected. The distribution of tree diameter by four diameter classes $(1=\mathrm{dbh} \geq 1 \mathrm{~cm} ; 2=\mathrm{dbh} \geq$ $5 \mathrm{~cm} ; 3=\mathrm{dbh} \geq 10 \mathrm{~cm}$; and $4=\mathrm{dbh} \geq 20 \mathrm{~cm}$ ) has revealed the existence of a typical inverse J-shaped curve distribution (Figure 2). The curve implies the presence of fewer larger 
TABle 3: Miombo woodland parameters describing biomass as studied in different sites.

\begin{tabular}{lcccccc}
\hline Forest name & $\begin{array}{c}\text { Number of } \\
\text { stems }(N)\end{array}$ & $\begin{array}{c}\text { Basal area } \\
(G)\left(\mathrm{m}^{2}\right)\end{array}$ & $\begin{array}{c}\text { Volume } \\
\left(\mathrm{m}^{3} / \mathrm{ha}\right)\end{array}$ & $\begin{array}{c}\text { Biomass } \\
(\mathrm{t} / \mathrm{ha})\end{array}$ & $\begin{array}{c}\text { Carbon stock } \\
(\mathrm{t} / \mathrm{ha})\end{array}$ & $\begin{array}{c}\mathrm{tCO} / \mathrm{ha} \\
\mathrm{equivalent}\end{array}$ \\
\hline Kingegenyanyembe & 1047 & 11.64 & 36.85 & 30.51 & 18.12 & 66.51 \\
Gangalamtumba & 493 & 8.39 & 110.56 & 91.70 & 45.85 & 168.27 \\
Kidundakiyave & 678 & 7.67 & 41.42 & 39.90 & 19.95 & 73.21 \\
Mandumburu & 680 & 7.91 & 58.63 & 119.01 & 59.51 & 218.39 \\
\hline
\end{tabular}

sized trees as compared to small diameter class trees. This is a normal tendency for naturally growing healthy forests $[3,18]$.

Moreover, stems density (stems per hectare) ranges from 495 to 1047 (Table 3). This implies the woodland is well stocked despite of domination of smaller diameter trees. There is variation in number of stems (N/ha) and volume $\left(\mathrm{Vm}^{3}\right)$ between study sites. This variation can be explained by specific environmental characteristics or the historical deforestation levels. According to Bongers and Tennigkeit [8], the density of miombo woodlands tree species differs with tree species and site specific characteristics.

Similar results have been reported in other miombo woodlands of Tanzania. For example, Kashinde et al. [53] and Mugasha et al. [54] reported stems per hectare of miombo woodlands to be between 355 and 1988. Elsewhere, Malmer [3] reported miombo woodland to have stand density ranges between 380 and 1400 stems per ha. The general trend from these results indicates the existence of wide variation in stand densities in miombo woodlands. This could be due to different age and species composition/structure or disturbance history $[2,13]$. This also can be related to the ability to regenerate mainly from resprouts, coppices, and stumps after anthropogenic disturbance. In Tanzania, the highest number of stems was reported from Duru Haitemba (1988 stems/ha) and Kitulagharo miombo woodlands (1027 stems/ha) while the lowest was Handeni Hill (355 stems/ha) [13].

3.2. Land Use and Cover Change Dynamics from 2000 before to 2013 after CBFM. It is known that evaluating conservation impacts of CBFM has some challenges including the establishment of base scenario $[50,60]$. In this study such challenges were resolved using biophysical data from ground based inventory, satellite images, and socioeconomic data. The results of land use and cover maps for the period 2000 and 2013 in all studied miombo woodlands have been summarized (Tables 4, 5, 6, and 7). The finding is that land use and cover change are increasing in favour of closed miombo woodlands. There is drastic increase of closed miombo woodlands of Gangalamtumba and Kidundakiyave (Tables 4 and 5) as compared to Kingegenyanyembe and Mandumburu (Tables 6 and 7). The general increase of closed miombo woodlands provides positive insight for community based forest management to be potential in mitigation of climate change strategy. On the other hand, results from participatory rapid appraisal (PRA) study have also revealed the increased regeneration in open and bushed grasslands to almost closed woodlands due to the reduction of illegal activities under CBFM.
These findings are comparable to land use and cover change of Tanzania which was worst in 1980s to 1990s as the country lost about $12.7 \%$ of natural forests [20]. In addition, between the years 1990 and 2005, the country forest cover was declining at the rate of about 412,000 ha per annum $[4,5,20]$, which is equivalent to $1.1 \%$ of the country's total forest area. Although the accuracy of the figures is questionable [38], the figures are higher than the average for Africa (0.64 and 0.62 percent) and far higher than the world average ( 0.22 and 0.18 percent) based on FAO $[4,5]$.

When compared among different vegetation types of Tanzania, miombo woodlands pose more significant challenge [8]. Miombo woodlands are severely under threat of land use and cover change [1]. Conversion into agricultural lands leads to fragmentation and isolation; legal and illegal logging and extensive extraction for fuel wood and wild fire have been a continuing challenge $[61,62]$. The observed results of land use and cover change by this study are also in line with Godoy et al. 2012 [63]. According to Godoy et al. 2012 [63] the rate of deforestation in Tanzanian forest reserves was $1.3 \%$ year $^{-1}$ in 1990 to 2000 and decreased to $0.6 \%$ year $^{-1}$ in 2000 to 2007 and these changes were associated with PFM implementation.

3.3. Underlying Factors of Land Use and Cover Change in the Studied Miombo Woodlands. In order to have snap shot on the factors contributing to land use and cover change in Southern Highlands of Tanzania, PRA approach was employed. The overall underlying factors for land use change as perceived by local community were fire wood extraction (178), charcoal production (178), and livestock grazing (152) as well as bush fire and conversion to cultivated fields (Table 8). These figures can only be taken as approximate estimates; however due to lack of records, they provide insight on the most important factors. According to Backéus et al. [2] these are also among the factors influencing the dynamics of miombo woodlands in Tanzania. The conversion of miombo woodlands into agricultural lands leads to fragmentation and isolation [62]. Illegal logging and extensive extraction of fuel wood and bush fires have been a continuing challenge in miombo woodlands in Tanzania $[9,13]$, as shown elsewhere $[1,61]$.

Confounding factors like changes over time and/or differences between forest reserves are being related to market access and prices of forest products, agricultural products, and livelihood strategies of local communities. However, the demand for goods and services from miombo woodlands is increasing and unsustainable utilization transforms the woodland into other more profitable land uses. The practice 
TABLE 4: Land use and miombo cover change before and after CBFM, Gangalamtumba.

\begin{tabular}{|c|c|c|c|c|c|c|c|}
\hline \multirow{2}{*}{ Land use type } & \multicolumn{2}{|c|}{2000 (before) } & \multicolumn{2}{|c|}{2013 (after) } & \multicolumn{2}{|c|}{$2000-2013$} & \multirow{2}{*}{$\begin{array}{c}\text { 2000-2013 } \\
\text { Annual rate of } \\
\text { change (ha/year) }\end{array}$} \\
\hline & $\begin{array}{l}\text { Cover area } \\
\text { (ha) }\end{array}$ & $\begin{array}{c}\text { Cover } \\
\text { coverage (\%) }\end{array}$ & $\begin{array}{l}\text { Cover area } \\
\text { (ha) }\end{array}$ & $\begin{array}{c}\text { Cover } \\
\text { coverage }(\%)\end{array}$ & $\begin{array}{c}\text { Cover change } \\
\text { area (ha) }\end{array}$ & $\begin{array}{c}\text { Cover change } \\
(\%)\end{array}$ & \\
\hline Closed woodland & 431.01 & 7.1 & 594.54 & 9.7 & 163.53 & 2.6 & 12.6 \\
\hline Open woodland & 4439.43 & 72.4 & 3933.27 & -64.2 & -506.16 & -8.2 & -38.9 \\
\hline Bushed grassland & 1054.8 & 17.2 & 1417.32 & 23.1 & 362.52 & 5.9 & 27.9 \\
\hline Cultivated lands & 136.26 & 2.2 & 107.01 & -1.8 & -29.25 & -0.4 & -2.3 \\
\hline Unclassified land & 66.6 & 1.1 & 75.96 & 1.2 & 9.36 & 0.1 & 0.7 \\
\hline Total & 6128.1 & 100 & 6128.1 & 100 & & & \\
\hline
\end{tabular}

NB: closed miombo woodland has canopy cover more than $40 \%$ while open woodland has $10 \%$ to $40 \%$.

TABLE 5: Land use and miombo cover change before and after CBFM, Kidundakiyave.

\begin{tabular}{|c|c|c|c|c|c|c|c|}
\hline \multirow{2}{*}{ Land use type } & \multicolumn{2}{|c|}{2000 (before) } & \multicolumn{2}{|c|}{2013 (after) } & \multicolumn{2}{|c|}{$2000-2013$} & \multirow{2}{*}{$\begin{array}{c}\text { 2000-2013 } \\
\text { Annual rate of } \\
\text { change (ha/year) }\end{array}$} \\
\hline & $\begin{array}{c}\text { Cover area } \\
\text { (ha) }\end{array}$ & $\begin{array}{c}\text { Cover } \\
\text { coverage }(\%)\end{array}$ & $\begin{array}{l}\text { Cover area } \\
\text { (ha) }\end{array}$ & $\begin{array}{c}\text { Cover } \\
\text { coverage }(\%)\end{array}$ & $\begin{array}{c}\text { Cover change } \\
\text { area (ha) }\end{array}$ & $\begin{array}{c}\text { Cover change } \\
(\%)\end{array}$ & \\
\hline Closed woodland & 598.32 & 11.8 & 754.29 & 14.8 & 155.97 & 3 & 12 \\
\hline Open woodland & 2682.36 & 52.8 & 3101.67 & 61 & 419.31 & 8.2 & 32.3 \\
\hline Bushed grassland & 1496.34 & 29.4 & 1057.05 & 20.8 & -439.29 & -8.6 & -33.8 \\
\hline Cultivated lands & 144.45 & 2.8 & 103.14 & 2 & -41.31 & -0.8 & -3.2 \\
\hline Unclassified land & 163.62 & 3.2 & 68.94 & 1.4 & -94.68 & -1.8 & -7.3 \\
\hline Total & 5085.09 & 100 & 5085.09 & 100 & & & \\
\hline
\end{tabular}

TABLE 6: Land use and miombo cover change before and after CBFM, Kingegenyanyembe.

\begin{tabular}{|c|c|c|c|c|c|c|c|}
\hline \multirow{2}{*}{ Land use type } & \multicolumn{2}{|c|}{2000 (before) } & \multicolumn{2}{|c|}{2013 (after) } & \multicolumn{2}{|c|}{ 2000-2013 } & \multirow{2}{*}{$\begin{array}{c}\text { 2000-2013 } \\
\text { Annual rate of } \\
\text { change (ha/year) }\end{array}$} \\
\hline & $\begin{array}{l}\text { Cover area } \\
\text { (ha) }\end{array}$ & $\begin{array}{c}\text { Coverage } \\
(\%)\end{array}$ & $\begin{array}{l}\text { Cover area } \\
\text { (ha) }\end{array}$ & $\begin{array}{c}\text { Cover } \\
\text { coverage (\%) }\end{array}$ & $\begin{array}{c}\text { Cover change } \\
\text { area (ha) }\end{array}$ & $\begin{array}{c}\text { Cover change } \\
(\%)\end{array}$ & \\
\hline Closed woodland & 271.62 & 52.9 & 318.51 & 62 & 46.89 & 9.1 & 3.6 \\
\hline Open woodland & 81.09 & 15.8 & 161.55 & 31.5 & 80.46 & 15.7 & 6.2 \\
\hline Bushed grassland & 136.98 & 26.7 & 0 & 0 & -136.98 & -26.7 & -10.5 \\
\hline Cultivated land & 19.08 & 3.7 & 26.82 & 5.2 & 7.74 & 1.5 & 0.6 \\
\hline Unclassified land & 4.59 & 0.9 & 6.48 & 1.3 & 1.89 & 0.4 & 0.2 \\
\hline Total & 513.36 & 100 & 513.36 & 100 & & & \\
\hline
\end{tabular}

has implications for ecosystem carbon stocks and miombo woodland resources availability [19]. Data derived from stump level measurements also revealed that charcoal making and firewood extraction are most significant activities in the studied miombo woodlands (Table 9).

Other scholars, for example, [7, 64], support the observation that fuel wood extraction is a significant cause of deforestation in miombo woodlands. Wood fuel is accounting for about $91 \%$ of total energy and about $95 \%$ of total wood consumed in Tanzania [9]. If we compared stump level measurement as categorized by local guide to whether the cutting was done probably before CBFM and after CBFM, the results have revealed reduction of cutting intensity under CBFM (Table 10). However, the extraction has been more remarkable to some miombo woodlands tree species.

For example, species of Brachystegia spiciformis and Brachystegia microphylla have more biomass extracted than the other tree species (Table 11). According to Luoga et al. [65], these miombo woodlands tree species has been commonly used for fuel wood production in Tanzania.

3.4. The Influence of CBFM on the Improvement of Miombo Woodland Biomass. Woody biomass and covers density are important indicators of the potential of forests to provide various products and services including carbon sequestration $[24,25]$. Based on the results from forest inventory data analysis, this study revealed more biomass in CBFM as compared to business as usual (Figure 3). The biomass improvement is higher in Mandumburu and Gangalamtumba as compared to other woodlands. This can be related to the initial condition of the forest before the implementation of community based forest management.

Across the study sites biomass for carbon stock improvement under CBFM versus non-CBFM was significant 
TABLE 7: Land use and miombo cover change before and after CBFM in Mandumburu.

\begin{tabular}{|c|c|c|c|c|c|c|c|}
\hline \multirow{2}{*}{ Land use type } & \multicolumn{2}{|c|}{2000 (before) } & \multicolumn{2}{|c|}{2013 (after) } & \multicolumn{2}{|c|}{$2000-2013$} & \multirow{2}{*}{$\begin{array}{c}\text { 2000-2013 } \\
\text { Rate of change } \\
\text { (ha/year) }\end{array}$} \\
\hline & $\begin{array}{c}\text { Cover area } \\
\text { (ha) }\end{array}$ & $\begin{array}{c}\text { Coverage } \\
(\%)\end{array}$ & $\begin{array}{c}\text { Cover area } \\
\text { (ha) }\end{array}$ & $\begin{array}{c}\text { Coverage } \\
(\%)\end{array}$ & $\begin{array}{c}\text { Change area } \\
\text { (ha) }\end{array}$ & $\begin{array}{c}\text { Change } \\
(\%)\end{array}$ & \\
\hline Closed woodland & 85.05 & 35.99 & 98.95 & 41.87 & 13.9 & 16.34 & 1.07 \\
\hline Open woodland & 90.36 & 38.24 & 84.38 & 35.71 & -5.98 & -6.62 & -0.46 \\
\hline Bushed grassland & 20.52 & 8.68 & 18.85 & 7.98 & -1.67 & -8.14 & -0.13 \\
\hline Cultivated lands & 17.08 & 7.23 & 19.08 & 8.07 & 2.00 & 11.71 & 0.15 \\
\hline Unclassified land & 23.31 & 9.86 & 15.06 & 6.37 & -8.25 & -35.39 & -0.63 \\
\hline Total & 236.32 & 100 & 236.32 & 100 & & & \\
\hline
\end{tabular}

TABLE 8: Factors for land use and miombo woodlands cover change as perceived by local communities.

\begin{tabular}{|c|c|c|c|c|c|}
\hline \multirow{2}{*}{ Underlying factors } & \multicolumn{5}{|c|}{ Respondents perception from different study sites } \\
\hline & $\begin{array}{c}\text { Gangalamtumba } \\
(n=64)\end{array}$ & $\begin{array}{l}\text { Kidundakiyave } \\
\quad(n=48)\end{array}$ & $\begin{array}{l}\text { Mandumburu } \\
\quad(n=46)\end{array}$ & $\begin{array}{c}\text { Kingegenyanyembe } \\
(n=60)\end{array}$ & $\begin{array}{c}\text { Overall score } \\
(n=218)\end{array}$ \\
\hline Charcoal production & 56 & 40 & 38 & 44 & 178 \\
\hline Fire wood extraction & 47 & 41 & 36 & 51 & 175 \\
\hline Livestock grazing & 28 & 36 & 41 & 47 & 152 \\
\hline Cultivated fields & 21 & 16 & 34 & 18 & 89 \\
\hline Construction materials & 23 & 18 & 25 & 17 & 83 \\
\hline Forest fires & 12 & 9 & 19 & 20 & 60 \\
\hline Plantation establishments & 22 & 15 & 14 & 9 & 60 \\
\hline Encroachments & 7 & 15 & 9 & 21 & 52 \\
\hline Human population & 11 & 13 & 6 & 15 & 45 \\
\hline Others & 5 & 9 & 12 & 8 & 34 \\
\hline
\end{tabular}

TABLE 9: Activities and stump density indicating extraction level in miombo woodlands.

\begin{tabular}{lcc}
\hline $\begin{array}{l}\text { Associated cause of } \\
\text { extraction }\end{array}$ & $\begin{array}{c}\text { Stump density } \\
(\mathrm{N} / \mathrm{ha})\end{array}$ & Proportion (\%) \\
\hline Charcoal making & 234 & 50 \\
Fire wood & 107 & 22.86 \\
Poles & 73 & 15.60 \\
Timber & 54 & 11.54 \\
\hline Total & 468 & 100 \\
\hline
\end{tabular}

$(P<5 \%)$, which on average ranged from $0.843 \mathrm{t} / \mathrm{ha}$ to $2.092 \mathrm{t} / \mathrm{h}$. This is equivalent to the increase in carbon storage potentials from $0.422 \mathrm{t} /$ ha to $1.046 \mathrm{t} / \mathrm{ha}$. However comparison of biomass improvement within the two scenarios was not statistically significant $(P>5 \%)$, showing that biomass improvement due to spatial natural variation is consistent across the four sites. Great variation in carbon stock between CBFM and non-CBFM sites is attributed to management effect. Therefore, climate change mitigation strategies should consider this improvement to motivate community based forest management efforts.

3.5. The Proportion of Biomass and Carbon by Different Miombo Woodlands Species. The study has revealed that on

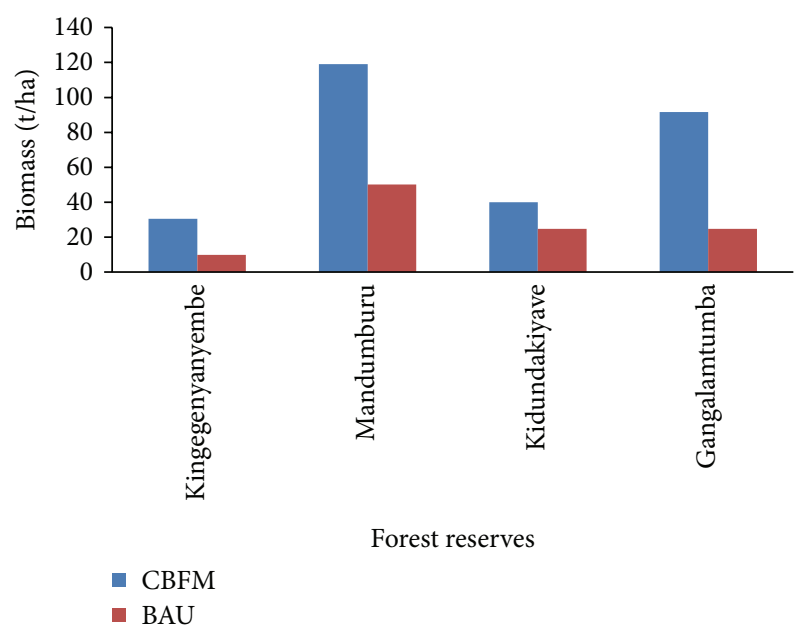

FIGURE 3: Miombo woodland biomass with (CBFM) and without (BAU).

average Brachystegia tree species are contributing significantly compared to other tree species of the miombo woodlands (Table 12). According to Backéus et al. [2], miombo vegetation is characterized by the dominance of Brachystegia species either alone or in association with Julbernardia species and Isoberlinia species. This type of vegetation is most dominant in the Zambezian floristic region [66]. 
TABLE 10: Extent of woodland extraction before and after CBFM based on stumps $(n=120)$.

\begin{tabular}{lccccc}
\hline Periods & $\begin{array}{c}\text { Density } \\
(\mathrm{N} / \mathrm{ha})\end{array}$ & $\begin{array}{c}\text { Basal area } \\
\left(\mathrm{m}^{2} / \mathrm{ha}\right)\end{array}$ & $\begin{array}{c}\text { Volume } \\
\left(\mathrm{m}^{3} / \mathrm{ha}\right)\end{array}$ & $\begin{array}{c}\text { Biomass } \\
(\mathrm{t} / \mathrm{ha})\end{array}$ & $\begin{array}{c}\text { Carbon stock } \\
(\mathrm{t} / \mathrm{ha})\end{array}$ \\
\hline New stumps & $137 \pm 12$ & $1.78 \pm 2.31$ & $9.63 \pm 2.35$ & $7.89 \pm 0.3$ & $3.95 \pm 0.41$ \\
Old stumps & $331 \pm 29$ & $4.69 \pm 2.72$ & $15.41 \pm 3.09$ & $13.77 \pm 0.8$ & $6.88 \pm 0.62$ \\
Overall & $468 \pm 23$ & $6.47 \pm 5.08$ & $25.04 \pm 5.44$ & $21.66 \pm 1.04$ & $10.83 \pm 1.03$ \\
\hline
\end{tabular}

${ }^{*}$ NB: new and old stumps differentiated by local guide based on appearance and experience.

TABLE 11: Removed biomass and carbon stock from most extracted miombo woodlands species.

\begin{tabular}{lccc}
\hline Scientific name & $\begin{array}{c}\text { Biomass } \\
(\mathrm{t} / \mathrm{ha})\end{array}$ & $\begin{array}{c}\text { Carbon } \\
(\mathrm{t} / \mathrm{ha})\end{array}$ & $\begin{array}{c}\text { Proportion } \\
(\%)\end{array}$ \\
\hline Brachystegia spiciformis & 3.47 & 1.74 & 35.01 \\
Brachystegia microphylla & 2.62 & 1.31 & 26.36 \\
Parinari curatellifolia & 1.98 & 0.99 & 19.92 \\
Combretum molle & 1.03 & 0.52 & 10.46 \\
\hline
\end{tabular}

TABLE 12: The contribution of biomass and carbon storage proportion by selected species.

\begin{tabular}{lccc}
\hline Scientific name & $\begin{array}{c}\text { Biomass } \\
(\mathrm{t} / \mathrm{ha})\end{array}$ & $\begin{array}{c}\text { Carbon } \\
\text { (ton/ha) }\end{array}$ & $\begin{array}{c}\text { Contribution } \\
(\%)\end{array}$ \\
\hline $\begin{array}{l}\text { Brachystegia } \\
\text { microphylla }\end{array}$ & 14.91363 & 7.456814 & 56.82151 \\
Brachystegia sp & 4.395013 & 2.197506 & 16.74517 \\
Coffea eugenioides & 1.701942 & 0.850971 & 6.484466 \\
Brachystegia & 1.024052 & 0.512026 & 3.901677 \\
spiciformis & & & \\
Combretum molle G. & 0.637697 & 0.318849 & 2.429651 \\
Brachystegia boehmii & 0.613336 & 0.306668 & 2.336833 \\
Maerua triphylla A. & 0.407514 & 0.203757 & 1.552646 \\
Albizia antunesiana & 0.318144 & 0.159072 & 1.212141 \\
Zanha africana & 0.315989 & 0.157994 & 1.20393 \\
Faurea rochetiana & 0.24015 & 0.120075 & 0.914982 \\
Parinari curatellifolia & 0.200373 & 0.100187 & 0.76343 \\
Erythrina abyssinica & 0.189471 & 0.094736 & 0.721893 \\
Brachystegia bussei & 0.142818 & 0.071409 & 0.544141 \\
Vitex doniana & 0.140025 & 0.070012 & 0.533499 \\
Tamarindus indica & 0.131409 & 0.065704 & 0.500672 \\
Opilia amentacea & 0.131042 & 0.065521 & 0.499274 \\
\hline
\end{tabular}

The contributions from other species though small are important in aggregate term. The selective harvesting of most suitable fuel wood tree species may reduce the abundance of some species and results to reduced carbon storage potentials.

\section{Conclusions and Implication for Climate Change Mitigation Policy}

This study used both ground based forest inventory techniques and satellite images to analyze land use and cover change in miombo woodlands under community based forest management. In this way it has been possible to quantify land use and cover change in miombo woodlands as results of community based forest management. While other land uses are decreasing in expense of increasing denser miombo woodland cover and biomass under CBFM, the implication for climate change mitigation potential is promising. Economic activities including charcoal making, fire wood extraction, and cultivation are found to have contributed greatly to the land use and cover change before and without CBFM. CBFM has enforced local bylaws and management plan to facilitate sustainable management and utilization of woodland resources. It has developed local community solidarity, cohesion, and social control of miombo woodland illegal extraction. This can facilitate permanence, reduce leakage, and increase accountability in the aspect of climate change mitigation.

Risk of leakage might be minimal since existing information from focused group discussion revealed that CBFM apart from regulating wood extraction on CBFM woodlands has also regulated sustainable use of resources on non-CBFM woodlands. Again CBFM facilitates efficiency use of fuel wood using improved stoves and enhancing skills on charcoal making practices. All these were strategies undertaken in line with CBFM geared towards ensuring minimal transfer of deforestation from CBFM woodlands to the adjacent unreserved woodlands. Good land use plan at village level and introduction of alternative income generating activities such as agroforestry and beekeeping could be among the best options to further reduce land use change and biomass loss in miombo woodlands.

\section{Conflict of Interests}

The authors declare that there is no conflict of interests regarding the publication of this paper.

\section{Acknowledgments}

Gratitude is expressed to the Tanzanian and Norwegian governments for financing this work. Appreciation is also extended to the Ministry of Natural Resources and Tourism, Forestry Training Institute, Olmotonyi Arusha Tanzania, and Sokoine University of Agriculture for the institutional support. Local community in Iringa region, Tanzania, who are taking care of the forest resources are thanked for their support. Thanks are due to Mr. Simon Kitereja for assisting on cover change analysis. Mr. Z. J. Lupala also thanks his 
wife Angela and his children Adventina, Gracy, Gregory, and Harvard for the moral and material support, particularly the love they entrenched over him. The authors thank God for life and all.

\section{References}

[1] B. Campbell, A. Angelsen, A. Cunningham, Y. Katerere, A. Sitoe, and S. Wunder, Miombo Woodlands-Opportunities and Barriers to Sustainable Forest Management, CIFOR, Bogor, Indonesia, 2007.

[2] I. Backéus, B. Pettersson, L. Strömquist, and C. Ruffo, "Tree communities and structural dynamics in miombo (Brachystegia-Julbernardia) woodland, Tanzania," Forest Ecology and Management, vol. 230, no. 1-3, pp. 171-178, 2006.

[3] A. Malmer, "General ecological features of miombo woodlands and considerations for utilization and management," in MITMIOMBO-Management of Indigenous Tree Species for Ecosystem Restoration and Wood Production in Semi-Arid Miombo Woodlands in Eastern Africa: Proceedings of the 1st MITMIOMBO Project Workshop held in Morogoro, Tanzania, pp. 6-12, 2007.

[4] FAO, State of the World's Forests 2007, Food and Agriculture Organization of the United Nations, Rome, Italy, 2007.

[5] FAO, "Global forest resources assessment: options and recommendation for a global remote sensing survey of forests," Forest Resources Assessment Programme Working Paper 141, Food and Agriculture Organization of the United Nations, Rome, Italy, 2007.

[6] United Republic of Tanzania (URT), Participatory Forest Management: Facts and Figures, Forestry and Beekeeping Division, Ministry of Natural Resources and Tourism, Dar es Salaam, Tanzania, 2006.

[7] E. Zahabu, Sinks and sources: a strategy to involve forest communities in Tanzania in global climate policy [Ph.D. thesis], University of Twente, Enschede, The Netherlands, 2008.

[8] F. Bongers and T. Tennigkeit, Eds., Degraded Forests in Eastern Africa: Management and Restoration, Earthscan Publications, London, UK, 2010.

[9] L. P. Lusambo, Economics of household energy in miombo woodlands of Eastern and Southern Tanzania [Philosophie Doctor thesis], School of the Environment and Natural Resources, University of Bangor, Bangor, UK, 2009.

[10] Y. M. Ngaga, G. C. Kajembe, S. A. O. Chamshama, T. T. Meilby H, J. F. Burgess N, and Brockington, "Brief Midterm Report Applied Research in Participatory Forest Management (PFM): Assessing under which conditions PFM contribute to the goals of poverty reduction, sustainable forest management and improved local governance in Tanzania," 2009.

[11] Z. J. Lupala, Assessment of miombo woodland tree species diversity and management practices for local livelihoods. A case study of Bereku miombo woodlands of Babati district, ManyaraTanzania [M.S. thesis], Swedish University of Agricultural Sciences (SLU), Uppsala, Sweden, 2009.

[12] J. M. Abdallah and G. G. MMonela, "Overview of miombo woodlands in Tanzania," Working Papers of the Finnish Forest Research Institute 50, Finnish Forest Research Institute, 2007.

[13] Z. J. Lupala, L. P. Lusambo, and Y. M. Ngaga, "Management, growth, and carbon storage in miombo woodlands of Tanzania," International Journal of Forestry Research, vol. 2014, Article ID 629317, 11 pages, 2014.
[14] W. L. Kutsch, L. Merbold, W. Ziegler et al., "The charcoal trap: miombo forests and the energy needs of people," Carbon Balance and Management, vol. 6, article 5, 2011.

[15] World Bank, Sustaining Forests: A Development Strategy, World Bank, Washington, DC, USA, 2004.

[16] S. A. H. Milledge, I. K. Gelvas, and A. Ahrends, Forestry, Governance and National Development: Lessons Learned from a Logging Boom in Southern Tanzania, TRAFFIC East, Southern Africa, Tanzania Development Partners Group, Ministry of Natural Resources of Tourism, Dar es Salaam, Tanzania, 2007.

[17] I. Bond, M. Chambwera, B. Jones, M. Chunduma, and Nhantumbo, REDD+ in Dryland Forests: Issues and prospects for pro-poor REDD in the Miombo woodlands of Southern Africa, Natural Resources Issues No.21, IIED, London, UK, 2010.

[18] J. Grace, J. S. José, P. Meir, H. S. Miranda, and R. A. Montes, "Productivity and carbon fluxes of tropical savannas," Journal of Biogeography, vol. 33, no. 3, pp. 387-400, 2006.

[19] M. Williams, C. M. Ryan, R. M. Rees, E. Sambane, J. Fernando, and J. Grace, "Carbon sequestration and biodiversity of regrowing miombo woodlands in Mozambique," Forest Ecology and Management, vol. 254, no. 2, pp. 145-155, 2008.

[20] FAO, Global Forest Resources Assessment 2010: Country Report, United Republic of Tanzania, Food and Agriculture Organization of the United Nations, Rome, Italy, 2010.

[21] M. M. Araya and O. Hofstad, "Monetary incentives to avoid deforestation under the Reducing emissions from deforestation and degradation (REDD+) climate change mitigation scheme in Tanzania," Mitigation and Adaptation Strategies for Global Change, 2014.

[22] G. Kissinger, M. Herold, and V. D. Sy, Drivers of Deforestation and Forest Degradation: A Synthesis Report for REDD+ Policymakers, Lexeme Consulting, Vancouver, Canada, 2012.

[23] D. Bowler, L. Buyung-Ali, J. R. Healey, J. P. G. Jones, T. M. Knight, and A. S. Pullin, "The evidence base for community forest management as a mechanism for supplying global environmental benefits and improving local welfare," CEE Review 08-011 (SR48), CEE, 2010.

[24] H. K. Gibbs, S. Brown, J. O. Niles, and J. A. Foley, "Monitoring and estimating tropical forest carbon stocks: Making REDD a reality," Environmental Research Letters, vol. 2, no. 4, 2007.

[25] FAO, Terrestrial Essential Climate Variables for Climate Change Assessment, Mitigation and Adaptation (GTOS 52), Food and Agriculture Organization of the United Nations, 2008.

[26] IPCC, 4th Assessment Report: Climate Change, Institute of Environmental Strategies, Kanagawa, Japan, 2007.

[27] UNFCCC, United Nations Framework Convention on Climate Change Report on the Second Workshop on Reducing Emissions from Deforestation in Developing Countries, UNFCCC, Bonn, Gernmany, 2007.

[28] United Nations Framework Convention on Climate Change (UNFCCC), "Decisions adopted by COP 16 and CMP 6. Cancun Climate Change Conference," UNFCCC, Bonn, Germany, 2010, http://unfccc.int/meetings/cop_16/items/5571.php.

[29] W. F. Laurance, "A new initiative to use carbon trading for tropical forest conservation," Biotropica, vol. 39, no. 1, pp. 2024, 2007.

[30] W. Sunderlin, J. Hatcher, and M. Liddle, From Exclusion to Ownership? Challenges and Opportunities in Advancing Forest Tenure Reform, Rights and Resources Initiative, Washington DC, USA, 2008. 
[31] T. Blomley, Lessons Learned from Community Forestry in Africa and Their Relevance for REDD+, USAID Supported Forest Carbon, Markets and Communities (FCMC) Program, Washington, DC, USA, 2013.

[32] M. M. Skutsch, P. E. Laake, E. Zahabu, B. S. Karky, and P. Phartiyal, "The value and the feasibility of community monitoring of biomass under REDD+," 2014, http://www.communitycarbonforestry.org/NewPublications/CIFOR\%20paper\%20Nov \%205\%20version.pdf.

[33] A. Chhatre and A. Agrawal, "Trade-offs and synergies between carbon storage and livelihood benefits from forest commons," Proceedings of the National Academy of Sciences of the United States of America, vol. 106, no. 42, pp. 17667-17670, 2009.

[34] L. Tacconi, "Decentralization, forests and livelihoods: theory and narrative," Global Environmental Change, vol. 17, no. 3-4, pp. 338-348, 2007.

[35] T. Blomley and S. Iddi, Participatory Forest Management 19932009: Lessons Learned and Experience to Date, United Republic of Tanzania, 2009.

[36] V. G. Vyamana, "Participatory forest management in the eastern arc mountains of Tanzania: who benefits?" International Forestry Review, vol. 11, no. 2, pp. 239-253, 2009.

[37] MNRT, Participatory Forest Management in Tanzania, Facts and Figures, United Republic of Tanzania Ministry of Natural Resources and Tourism, Forestry and Beekeeping Division, Dar es salaam, Tanzania, 2008.

[38] MNRT, National Forestry Resources Monitoring and Assessment (NAFORMA) of Tanzania, Field manual, Biophysical Survey, Ministry of Natural Resources \& Tourism, Dar Es Salaam, Tanzania, 2010.

[39] B. Adhikari, "Poverty, property rights and collective action: understanding the distributive aspects of common property resource management," Environment and Development Economics, vol. 10, no. 1, pp. 7-31, 2005.

[40] G. C. Kajembe, Y. M. Ngaga, S. A. O. Chamshama, and M. A. Njana, "Performance of participatory forest management regimes in Tanzania; preliminary findings in the Project 'apllied research in Tanzania,' in Proceedings of the 1st Participatory Forest Management Research Workshop (PFM '09), pp. 93-110, Participatory Forest Management for Improved Forest Quality, Livelihood and Governance, June 2009.

[41] T. Treue, Y. M. Ngaga, H. Meilby et al., "Does participatory forest management promote sustainable forest utilisation in Tanzania?" International Forestry Review, vol. 16, no. 1, pp. 2338, 2014.

[42] J. F. Lund and T. Treue, " Are we getting there? Evidence of decentralized forest management from Tanzanian miombo woodlands," World Development, vol. 36, no. 12, pp. 2780-2800, 2008.

[43] E. Ostrom, Understanding Institutional Diversity, Princeton University Press, Princeton, NJ, USA, 2009.

[44] J. Phelps, E. L. Webb, and A. Agrawal, "Does REDD+ Threaten to recentralize forest governance?” Science, vol. 328, no. 5976, pp. 312-313, 2010.

[45] M. Richard and T. Blomley, Getting Started on REDD in Tanzania: A Scoping Study for the Katoomba Ecosystem Services Incubator, vol. 24, East and Southern Africa Katoomba Group, 2009.

[46] A. Ahrends, N. D. Burgess, S. A. H. Milledge et al., "Predictable waves of sequential forest degradation and biodiversity loss spreading from an African city," Proceedings of the National
Academy of Sciences of the United States of America, vol. 107, no. 33, pp. 14556-14561, 2010.

[47] A. Angelsen, M. Brockhaus, M. Kanninen, E. Sills, W. D. Sunderlin, and S. Wertz-Kanounnikoff, Eds., Realizing REDD+: National Strategy and Policy Options, Center for International Forestry Research (CIFOR), Bogor, Indonesia, 2009.

[48] M. Skutsch and S. M. Solis, "How much carbon does community forest management save?" in Community Forest Monitoring for the Carbon Market: Opportunities under REDD, M. Skutsch, Ed., chapter 2, Earthscan, London, UK, 2011.

[49] Village Government Records for Green Resource Limited, "Reforestation in grassland areas of Idete, Mufindi district, Iringa region, Tanzania," CCB-AR-PDD Report, Village Government Records for Green Resource Limited, Mafinga, Tanzania, 2013.

[50] J. F. Lund, K. Balooni, and T. Casse, "Change we can believe in? Reviewing studies on the conservation impact of popular participation in forest management," Conservation and Society, vol. 7, no. 2, pp. 71-82, 2009.

[51] K. MacDicken, "A guide to monitoring carbon storage in forestry and agroforestry projects," Report 1611, N. Winrock International Institute for Agricultural, 1997.

[52] IPCC, Good Practice Guidance for Land-Use Changes and Forestry, Institute of Environmental Strategies, Kanagawa, Japan, 2003.

[53] A. Kashinde, E. Mtalo, M. Mpanda, E. Liwa, and R. Giliba, "Multi-temporaral assessment of forest cover, stocking parameters and above-ground tree biomass dynamics in miombo woodlands of Tanzania," African Journal of Environmental Science and Technology, vol. 7, no. 7, pp. 611-623, 2013.

[54] W. A. Mugasha, O. M. Bollandsås, R. E. Malimbwi et al., "Allometric models for prediction of above- and belowground biomass of trees in the miombo woodlands of Tanzania," Forest Ecology and Management, vol. 310, pp. 87-101, 2013.

[55] R. E. Malimbwi, E. Zahabu, G. C. Monela, S. Misana, G. C. Jambiya, and B. Mchome, "Charcoal potential of miombo woodlands at Kitulangalo, Tanzania," Journal of Tropical Forest Science, vol. 17, no. 2, pp. 197-210, 2005.

[56] J. J. Kashaigili and A. M. Majaliwa, "Integrated assessment of land use and cover changes in the Malagarasi river catchment in Tanzania," Physics and Chemistry of the Earth, vol. 35, no. 1314, pp. 730-741, 2010.

[57] A. Atesoglu and M. Tunay, "Spatial and temporal analysis of forest cover changes in the Bartin region of northwestern Turkey," African Journal of Biotechnology, vol. 9, no. 35, pp. 5676-5685, 2010.

[58] J. R. Jensen, Remote Sensing of the Environment: An Earth Resource Perspective, Prentice Hall, Upper Saddle River, NJ, USA, 2nd edition, 2007.

[59] C. F. Nachmias and D. Nachmias, Research Methods in the Social Science, St Martin's Press, New York, NY, USA, 5th edition, 1996.

[60] D. E. Bowler, L. M. Buyung-Ali, J. R. Healey, J. P. G. Jones, T. M. Knight, and A. S. Pullin, "Does community forest management provide global environmental benefits and improve local welfare?" CEE Review 08-011 (SR48), Environmental Evidence, 2010, http://www.environmentalevidence.org/SR48.html.

[61] L. Miles, K. Kabalimu, B. Bahane et al., Carbon, Biodiversity and Ecosystem Services: Exploring Benefits, Tanzania, Forestry and Beekeeping Division, United Nations Environment Programme World Conservation Monitoring Centre, Cambridge, UK, 2009. 
[62] B. Fisher, S. L. Lewis, N. D. Burgess et al., "Implementation and opportunity costs of reducing deforestation and forest degradation in Tanzania," Nature Climate Change, vol. 1, no. 3, pp. 161-164, 2011.

[63] F. L. Godoy, K. Tabor, N. D. Burgess, B. P. Mbilinyi, J. J. Kashaigili, and M. K. Steininger, "Deforestation and $\mathrm{CO}_{2}$ emissions in coastal Tanzania from 1990 to 2007," Environmental Conservation, vol. 39, no. 1, pp. 62-71, 2012.

[64] J. A. Isango, "Management of indigenous tree species for ecosystem restoration and wood production in semi-arid Miombo woodlands in East Africa," in Proceedings of the 1st MITMIOMBO Project Workshop, Working Papers of the Finnish Forest Research Institute 50, Morogoro, Tanzania, February 2007.

[65] E. J. Luoga, E. T. F. Witkowski, and K. Balkwill, "Harvested and standing wood stocks in protected and communal miombo woodlands of Eastern Tanzania," Forest Ecology and Management, vol. 164, no. 1-3, pp. 15-30, 2002.

[66] F. White, The Vegetation of Africa, vol. 20 of Natural Resources Research, UNESCO, Paris, France, 1983. 

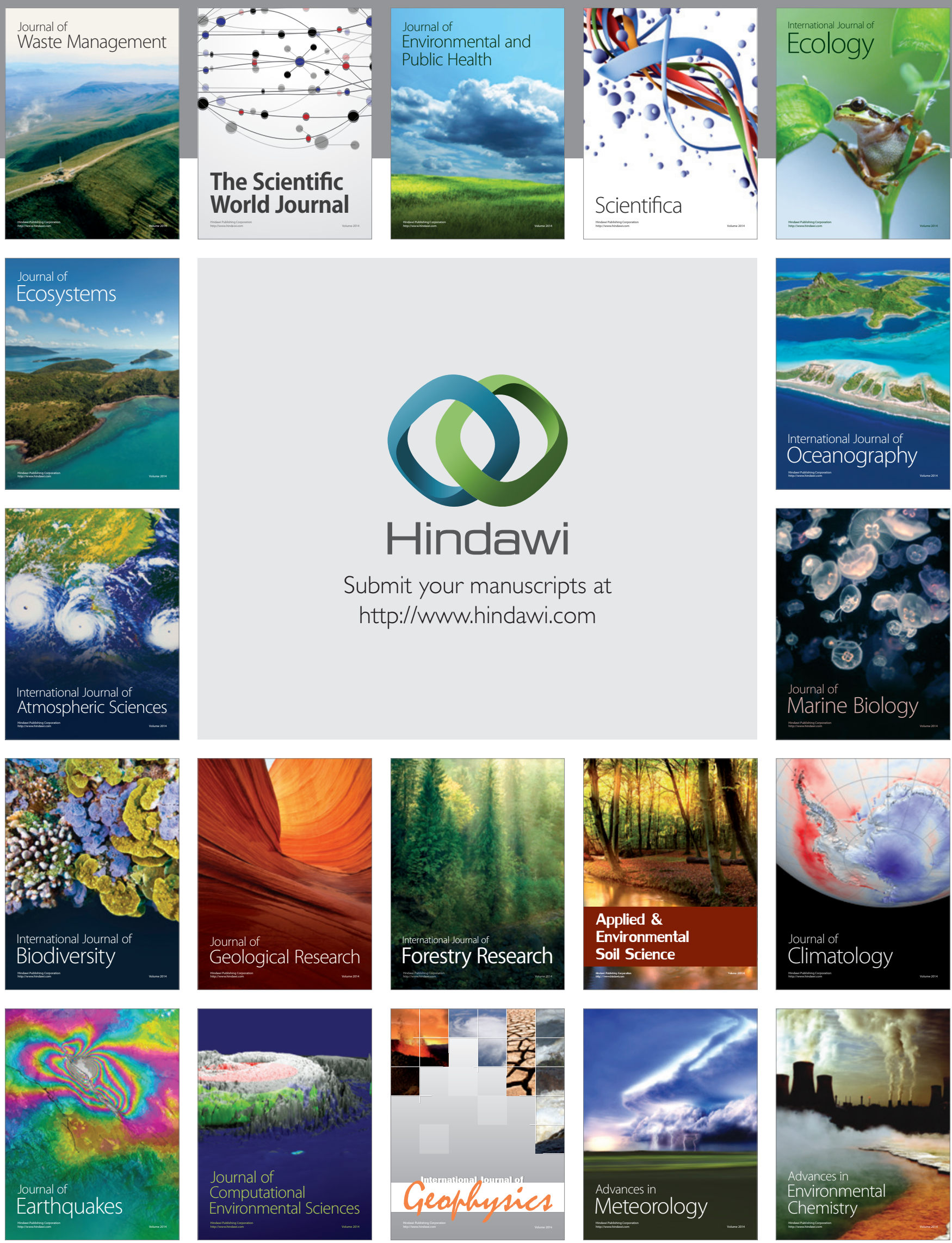